\title{
Sleep Quality in Pamukkale University Students and its relationship with smartphone addiction
}

\author{
Betul Ozcan ${ }^{1}$, Nurhan Meydan Acimis ${ }^{2}$
}

\begin{abstract}
Objective: Research shows that poor sleep quality and smartphone addiction are common problems among university students. This study was planned to evaluate the quality of sleep in students at Pamukkale University and to investigate its relationship with smartphone addiction.

Methods: This cross-sectional study was carried out at the university campus in 2017-2018. Its dependent variable was low sleep quality. Independent variables were smartphone addiction, features related to smartphone addiction, socio-demographic features and other questioned features. The total number of students attending normal education in seven faculties and two colleges for four years was 20862. The minimum sample size of the study was calculated as 1088. Smartphone Addiction Scale-Short Version (SAS-SV) and Pittsburgh Sleep Quality Index (PSQI) were used. The data were analyzed with the SPSS program.

Results: The mean age was of the participants $21.39 \pm 2.21$. The sleep quality of students with a PSQI total score of more than five was defined as 'poor'. The frequency of poor sleep quality was $52.4 \%$. The frequency of smartphone addiction was $34.6 \%$ according to the SAS-SV scale. It was found that the frequency of poor sleep quality was significantly higher in students with smartphone addiction compared to others.
\end{abstract}

Conclusion: Smartphone addiction was found as one of the risk factors for poor sleep quality.

KEYWORDS: Cell phone, Sleep, Students.

doi: https://doi.org/10.12669/pjms.37.1.3130

How to cite this:

Ozcan B, Acimis NM. Sleep Quality in Pamukkale University Students and its relationship with smartphone addiction. Pak J Med Sci. 2021;37(1):206-211. doi: https://doi.org/10.12669/pjms.37.1.3130

This is an Open Access article distributed under the terms of the Creative Commons Attribution License (http://creativecommons.org/licenses/by/3.0), which permits unrestricted use, distribution, and reproduction in any medium, provided the original work is properly cited.

1. Betul Ozcan, MD

Public Health Professional,

Provincial Health Directorate,

Agri Turkey.

2. Nurhan Meydan Acimis,

Department of Public Health,

Pamukkale University School of Medicine,

Denizli Turkey.

Correspondence:

Nurhan Meydan Acimis

Department of Public Health,

Pamukkale University School of Medicine,

Denizli Turkey.

E-mail: nurhan88@hotmail.com

* Received for Publication:

* $1^{\text {st }}$ Revision Received:

* $2^{\text {nd }}$ Revision Received:

* Final Revision Accepted: *
June 26, 2020

July 14,2020

September 23, 2020

October 15, 2020

\section{INTRODUCTION}

Lifestyle changes and environmental factors are increasingly affecting sleep quality. ${ }^{1}$ University students may have different sleep problems from their peers due to their lifestyles and academic responsibilities. ${ }^{2,3}$ Research shows that having poor sleep quality and smartphone addiction is a common problems among university students. ${ }^{4}$ Smartphone addiction is similar to internet addiction, and excessive use of smartphones can cause mental and behavioral problems. ${ }^{5,6}$ This study, aimed to investigate the quality of sleep in Pamukkale University students and to investigate its relationship with smartphone addiction. 


\section{METHODS}

This cross-sectional study was planned to be conducted with university students and at faculties in the campus in the 2017-2018 academic year. The dependent variable of the study was a poor sleep quality, and Pittsburgh Sleep Quality Index (PSQI) score higher than five indicates bad sleep quality. The minimum sample size was calculated as 1088 with a $95 \%$ confidence level and $80 \%$ power after examining the findings of other studies, with Open Epi (Open Source Epidemiologic Statistics for Public Health) Version $3.01 .^{7,8}$ This number was increased by $20 \%$ to prevent possible problems that may occur. Hence, we aimed to reach 1306 students. A multistage cluster sampling method was used to recruit university students. Schools and faculties were accepted as clusters, and five faculties and one vocational school and students in all classes, which were selected randomly among seven faculties and two colleges were located in the Kinikli campus. There were a total of 14 faculties and three colleges in Pamukkale University Kinikli Campus. There were no students in some of the classes. Five faculties and one college with students from only normal education were selected among seven four-year faculties and two colleges with students from all grades. In the 2017-2018 academic year, the total number of students in seven four-year faculties and two colleges attending normal education was 20862 . The questionnaire used in the study consisted of three sections that included a 30-item survey, a Smartphone Addiction Scale Short Form, and the Pittsburgh Sleep Quality Index. Smartphone Addiction Scale Short Form was developed by Kwon et al. ${ }^{9}$ Turkish validity and reliability was performed by Noyan et al. and Cronbach's alpha coefficient was $0.867 . .^{10}$ The Likert type scale was scored from one to six. The lowest and highest scores to be obtained from the scale were 10 and 60, respectively. The risk of smartphone addiction increased in line with the scale score. The cut off score was identified as 31 for men and
Table-I: Students' PSQI and SAS-SF scores.

\begin{tabular}{lcc}
\hline Variable & Number & Mean $\pm S D$ \\
\hline PSQI total score & 1545 & $6.17 \pm 3.03$ \\
SAS-SF score & & \\
Smartphone user & 1539 & $28.63 \pm 10.15$ \\
Not smartphone user & 6 & - \\
\hline
\end{tabular}

33 for women in SAS-SF, which did not have a sub-scale. The Pittsburgh Sleep Quality Index which evaluated the sleep quality the last month. It was developed by Buysse et al. ${ }^{7}$ The Turkish scale validity and reliability study was conducted by Aaargun et al and Cronbach's alpha coefficient was $0.80 .^{8}$ A total score of above five which ranges between 0 and 21 indicates a poor sleep quality. Ethical committee approval was obtained from Pamukkale University Non-Interventional Clinical Research Ethics Committee numbered 60116787-020/8328(2018) and Statistical Package for Social Sciences (SPSS) for Windows 17.0 package program was used for analysis.

\section{RESULTS}

Of the 1545 participant $56.8 \%$ were females and $43.2 \%$ were males. The mean age of students was $21.39 \pm 2.21$. Students' total PSQI mean score was $6.17 \pm 3.03$, and the mean SAS-SF score was $28.63 \pm$ 10.15 (Table-I). Of the students $52.4 \%$ had a PSQI total score higher than five and their sleep quality was poor. According to smartphone addiction cutoff points (31 points and above for men, 33 points and above for women), the frequency of addiction of students was $34.6 \%$ (35.9\% for females and $33.0 \%$ for males). Six students who did not use smartphones were included in the group without smartphone addiction. In the study group, the frequency of having poor sleep quality was $64.5 \%$ for those with smartphone addiction and $45.9 \%$ for those without. The frequency of poor sleep quality was significantly higher in students with smartphone addiction compared to those without smartphone addiction (Table-II).

Table-II: Comparison of students' sleep quality according to their smartphone addiction status.

\begin{tabular}{lcccc}
\hline \multirow{2}{*}{ Variable } & & \multicolumn{2}{c}{ Sleep Quality } & \\
\cline { 3 - 4 } & & Poor Number (\%) & Well Number (\%) & \\
\hline \multirow{2}{*}{ Smartphone Addiction } & Yes & $345(64.5)$ & $190(35.5)$ & $<0.001$ \\
\hline
\end{tabular}


Table-III: Comparison of students' sleep quality with other important variables.

\begin{tabular}{|c|c|c|c|}
\hline \multirow[t]{2}{*}{ Variable } & \multicolumn{2}{|c|}{ Sleep Quality } & \multirow[t]{2}{*}{$p$} \\
\hline & Poor Number (\%) & Well Number (\%) & \\
\hline \multicolumn{4}{|l|}{ Perceived income level } \\
\hline Income less than expenditures & $195(58.7)$ & $137(41.3)$ & \multirow[t]{3}{*}{0.016} \\
\hline Income is equal to expenditure & $452(51.1)$ & $432(48.9)$ & \\
\hline Income more than expenditures & $156(49.4)$ & $160(50.6)$ & \\
\hline \multicolumn{4}{|l|}{ Smoking status } \\
\hline Never smoked & $469(48.7)$ & $495(51.3)$ & \multirow[t]{4}{*}{$<0.001$} \\
\hline Quit smoking & $53(54.6)$ & $44(45.4)$ & \\
\hline Occasionally smokes & $104(56.8)$ & 79 (43.2) & \\
\hline Regular smoker & $183(61.0)$ & $117(39.0)$ & \\
\hline \multicolumn{4}{|l|}{ Alcohol use in the past month } \\
\hline Never uses & $584(50.6)$ & $570(49.4)$ & \multirow[t]{3}{*}{0.002} \\
\hline Less than 1 day a week & $137(52.7)$ & $123(47.3)$ & \\
\hline Consumes 1 day or more per week & $85(67.5)$ & $41(32.5)$ & \\
\hline \multicolumn{4}{|l|}{ Doing Regular Exercise } \\
\hline Yes & $228(47.2)$ & $255(52.8)$ & \multirow[t]{2}{*}{0.006} \\
\hline No & $578(54.7)$ & 478 (45.3) & \\
\hline \multicolumn{4}{|c|}{$\begin{array}{l}\text { Physical activity for at least } 150 \text { minutes moderate or } 75 \text { minutes intense } \\
\text { or an equivalent combination of the two in the last week }\end{array}$} \\
\hline Yes & $289(48.1)$ & $312(51.9)$ & \multirow[t]{2}{*}{0.004} \\
\hline No & $481(55.7)$ & $382(44.3)$ & \\
\hline \multicolumn{4}{|l|}{ Weekly coffee consumption } \\
\hline Not Consuming & $91(42.3)$ & $124(57.7)$ & \multirow[t]{3}{*}{$<0.001$} \\
\hline $1-10$ cups or cups / week & $516(52.1)$ & $475(47.9)$ & \\
\hline$>10$ glasses or cups / week> & $176(63.3)$ & $102(36.7)$ & \\
\hline \multicolumn{4}{|l|}{ Weekly caffeinated soft drink consumption } \\
\hline Not Consuming & $205(46.8)$ & $233(53.2)$ & \multirow[t]{3}{*}{0.002} \\
\hline $1-5$ cups or cans/week & $420(53.0)$ & $372(47.0)$ & \\
\hline$>5$ glasses or box/week> & $143(59.1)$ & $99(40.9)$ & \\
\hline \multicolumn{4}{|l|}{ Energy drink consumption in the last month } \\
\hline Never consumed in the last one month & $684(51.8)$ & $636(48.2)$ & \multirow[t]{3}{*}{0.047} \\
\hline Consumed 1-5 days in the last one month & $96(56.8)$ & $73(43.2)$ & \\
\hline Consumed more than 5 days in the past month & $22(66.7)$ & $11(33.3)$ & \\
\hline \multicolumn{4}{|l|}{ Hours of Caffeinated beverage consumption } \\
\hline During daytime & $128(43.2)$ & $168(56.8)$ & 0.001 \\
\hline In the evening (after 18 o'clock) & $210(54.8)$ & $173(45.2)$ & \\
\hline Both during the day and in the evening & $467(55.1)$ & $381(44.9)$ & \\
\hline Smartphone or tablet screen usage in the last One & before bedtime & & \\
\hline Yes & $651(53.9)$ & $557(46.1)$ & 0.042 \\
\hline No & 149 (47.5) & $165(52.5)$ & \\
\hline Using smartphone in bed not using & $66(42.0)$ & $91(58.0)$ & $<0.001$ \\
\hline$\leq 30$ minutes/ 24 hours & $247(45.5)$ & $296(54.5)$ & \\
\hline$>30$ minutes/24 hours & $443(60.0)$ & $295(40.0)$ & \\
\hline Disease diagnosed by a physician & & & \\
\hline Yes & $125(59.0)$ & $87(41.0)$ & 0.037 \\
\hline No & 677 (51.2) & $644(48.8)$ & \\
\hline Regular medication use & & & \\
\hline Yes & $93(60.0)$ & $62(40.0)$ & 0.042 \\
\hline No & $711(51.4)$ & $672(48.6)$ & \\
\hline First-degree relative with sleep problems & & & \\
\hline Yes & $181(65.8)$ & $94(34.2)$ & $<0.001$ \\
\hline No & $625(49.4)$ & $641(50.6)$ & \\
\hline & Median & Median & \\
\hline Daily internet usage time (Hours/day) & $4(4.97 \pm 2.96)$ & $4(4.61 \pm 2.85)$ & 0.011 \\
\hline Daily smartphone usage time (hours/day) & 5 & 4 & $<0.001$ \\
\hline
\end{tabular}


There was a positive correlation was found between the students PSQI total scores and SASSF scores (rho 0,242 $\mathrm{p}<0.001$ ). A statistically significant linear relationship was found between students' perceived financial status and their sleep quality (Table-III). Additionally, there were statistically significant relationships between students' frequency of poor sleep quality and their smoking and alcohol use habits. Those who did not exercise had a higher rate of poor sleep quality than those who did at least 150 minutes of moderate-intensity physical activity or at least 75 minutes of vigorous-intensity physical activity per week or an equivalent combination of these, as recommended by WHO for the 18-64 age group (Table-IV). There was a significant linear relationship between the weekly consumption of coffee, caffeinated soft drinks, and energy drinks in the last month and sleep quality. Also there was a significant difference between the time of consuming caffeinated beverages and the students sleep quality (Table-III).

Daily internet usage differed according to students' sleep quality: those with poor sleep quality had a significantly higher frequency of daily internet usage than others. The frequency of poor sleep quality was significantly higher in students using a smartphone or tablet within an hour before going to bed. The students with poor sleep quality had a significantly higher mean value of daily smartphone usage than others. The frequency of poor sleep quality increased in line with the frequency of smartphone usage, and there was a significant difference. The frequency of poor sleep quality significantly increased in the students who were diagnosed with a disease compared to those who were not in those who took regular medicines compared to those who did not, and in those who had a first-degree relative with sleep problems compared to those who did not (Table-IV).

In the multivariate analysis of factors related to the sleep quality of students, the variables which were significant in binary comparisons were evaluated using the binary logistic regression model. The risk of poor sleep quality was 1.937 times more significant in those with smartphone addiction than those without (Table-IV).

\section{DISCUSSION}

Of the participants $52.4 \%$ had a poor sleep quality and one of the independent risk factors was smartphone addiction. Although smartphone addiction is a social problem, it should be considered in clinical practice. Studies

Table-IV: Binary logistic regression analysis results.

\begin{tabular}{|c|c|c|c|}
\hline Variable (Reference) & (B) & $95 \% \mathrm{CI}$ & $p$ \\
\hline \multicolumn{4}{|l|}{ Smartphone addiction (No) } \\
\hline Yes & 1.937 & $1.486-2.524$ & $<0.001$ \\
\hline \multicolumn{4}{|c|}{ Perception of financial situation (Income is more than expenses) } \\
\hline Income is equal to expenditure & 1.278 & $0.935-1.747$ & 0.124 \\
\hline Income less than expenditures & 1.769 & $1.212-2.581$ & 0.003 \\
\hline \multicolumn{4}{|l|}{ Smoking status (Never smoked) } \\
\hline Quit Smoking & 1.173 & $0.695-1.981$ & 0.551 \\
\hline Occasionally smokes & 1.489 & $0.994-2.231$ & 0.054 \\
\hline Regular smoker & 1.510 & $1.064-2.142$ & 0.021 \\
\hline \multicolumn{4}{|l|}{ In the past one month, alcohol use (No) } \\
\hline Less than one day a week & 1.087 & $0.769-1.536$ & 0.638 \\
\hline Consumes one day or more per week & 1.798 & $1.095-2.951$ & 0.020 \\
\hline \multicolumn{4}{|c|}{$\begin{array}{l}\text { Physical activity for at least } 150 \text { minutes of moderate or } 75 \text { minutes } \\
\text { of intense or an equivalent combination of both in the last week (Yes) }\end{array}$} \\
\hline No & 1.696 & $1.319-2.180$ & $<0.001$ \\
\hline \multicolumn{4}{|c|}{ Having first-degree relatives with sleep problems (No) } \\
\hline Yes & 2.228 & $1.576-3.149$ & $<0.001$ \\
\hline \multicolumn{4}{|l|}{ Using a smartphone in bed (No) } \\
\hline$\leq 30$ minutes/24 hours & 1.062 & $0.687-1.644$ & 0.786 \\
\hline$>30$ minutes/ 24 hours & 1.800 & $1.172-2.764$ & 0.007 \\
\hline
\end{tabular}


conducted up to date with university students across the world have also reported a prevalence of poor sleep quality, which is consistent with our findings. ${ }^{11,12}$ This frequency was $59.4 \%$ in Lithuania, ${ }^{13} 52.7 \%$ in Lebanon, ${ }^{14} 55.8 \%$ in Ethiopia, ${ }^{15} 33.8 \%$ in Taiwan, ${ }^{16} 55 \%$ in the United States, ${ }^{17}$ and in Brazil $61.5 \%{ }^{18}$

A meta-analysis in Brazil found that children with low income levels had poorer sleep quality ${ }^{19}$ and these findings were in line findings of our study. Low perception of income level was an independent risk factor for poor sleep quality and this may be related to easy access to technological devices. Less poor sleep quality in students with high income perception may be related to the more conscious lifestyle created by financial opportunities in individuals.

Moreover, international scientific studies demonstrate the positive effects of exercise on sleep ${ }^{20,21}$ In this study, the students' levels of engagement in moderate-intensity and vigorousintensity physical activities over the last week were investigated and according to the binary logistic regression analysis, not doing physical activity at the level recommended by WHO was found to be an independent risk factor for poor sleep quality. This relationship was understandable considering the mental and physical positive effects of physical activity. In our study, the daily internet usage hours of students with poor sleep quality were significantly higher than others, and similarly, in studies conducted with university students in Taiwan, ${ }^{16}$ the sleep quality of students with internet addiction was found to be significantly worse.

Daily smartphone usage hours of students with poor sleep quality were also significantly higher than others. So, the increase in daily smartphone usage time may lead to smartphone addiction and cause poor sleep quality. A study on students in Japan reported that playing computer games before going to sleep delays sleep ${ }^{22}$ We did not find a significant relationship between digital gaming and students sleep quality, which may be due to the use of smartphones for other purposes than digital gaming. We found that having firstdegree relatives with sleep problems was a risk factor for poor sleep quality, which is also in line with the literature. In our study, the frequency of smartphone addiction was found to be $34.6 \%$, and similarly to the findings of previous studies, we found that smartphone addiction to poses risks for poor sleep quality.
Limitation of the study: Our strength was that we used valid and reliable scales for the study and investigated many variables related to sleep quality. Our limitation was that the study data were based on the participants statements.

\section{CONCLUSION}

Smartphone addiction was found to be one of the risk factors for poor sleep quality. Students should be informed about sleep quality and smartphone addiction. During their university education and smartphone addiction should be questioned in clinical applications with poor sleep quality problems.

Acknowledgments: This paper was produced from the first author's dissertation study. The dissertation was supported as a Pamukkale University BAP project. The paper was presented at the second National Denizli Family Medicine Congress (710 March 2019) as a podium presentation. Ethical committee approval was obtained from Pamukkale University for the study.

Funding: This study was supported by the decision of Pamukkale University Scientific Research Projects (BAP) Coordination Unit, 2018TIPF039.

Conflict of Interest: The authors declare no conflict of interest.

\section{REFERENCES}

1. World Health Organization Regional Office for Europe. WHO technical meeting on sleep and health; 2004 January 22-24; Bonn, Germany. Copenhagen: Denmark; WHO Regional Office for Europe. 2004;P:2-24.

2. Buboltz WC Jr, Brown F, Soper B. Sleep habits and patterns of college students: A preliminary study. J Am Coll Health. 2001;50(3):131-135. doi: 10.1080/07448480109596017

3. Fukuda K, Ishihara K. Age related changes of sleeping pattern during adolescence. Psychiatry Clin Neurosci. 2001;55(3):231-232. doi: 10.1046/j.1440-1819.2001.00837.x

4. Soni R, Upadhyay R, Jain M. Prevalence of smart phone addiction, sleep quality and associated behaviour problems in adolescents. Int J Res Med Sci. 2017;5(2):515-519.

5. Kim H. Exercise rehabilitation for smartphone addiction. J Exerc Rehabil. 2013;9(6):500-555. doi: 10.12965/jer.130080

6. Lemola S, Perkinson-Gloor N, Brand S, DewaldKaufmann JF, Grob A. Adolescents 'electronic media use at night, sleep disturbance, and depressive symptoms in the smartphone age. J Youth Adolesc. 2015;44(2):405-418. doi: 10.1007/s10964-014-0176-x

7. Buysse DJ, Reynolds CF 3rd, Monk TH, Berman SR, Kupfer DJ. The Pittsburgh Sleep Quality Index: A new instrument for psychiatric practice and research. Psychiatry Res. 1989;28(2):193-213. doi: 10.1016/01651781(89)90047-4 
8. Aaargun MY, Kara H, Anlar O. Pittsburgh Uyku Kalitesi Indeksi`nin Gecerligi ve Guvenirlig. Turk Psikiyatri Derg. 1996;7(2):107-115.

9. Kwon M, Kim DJ, Cho H, Yang S. The smartphone addiction scale: development and validation of a short version for adolescents. PLoS One 2013;8(12):835-858. doi: 10.1371/journal.pone.0083558

10. Noyan CO, Darcin AE, Nurmedov S, Yilmaz O, Dilbaz $\mathrm{N}$. Akilli telefon bagimliligi olceginin kisa formunun universite ogrencilerinde Turkce gecerlilik ve guvenilirlik calismasi. Anadolu Psikiyatri Derg. 2015;16(1):73-81.

11. Lai PP, Say YH. Associated factors of sleep quality and behavior among students of two tertiary institutions in Northern Malaysia. Med J Malaysia. 2013;68(3):196-203.

12. Rique GLN, Fernandes Filho GMC, Ferreira ADC, de Sousa-Muñoz RL. Relationship between chronotype and quality of sleep in medical students at the Federal University of Paraiba, Brazil. Sleep Sci 2014;7(2):96-102. doi: 10.1016/j.slsci.2014.09.004

13. Preisegolaviciute E, Leskauskas D, Adomaitiene V. Associations of quality of sleep with lifestyle factors and profile of studies among Lithuanian students. Medicina (Kaunas). 2010;46(7):482-9.

14. Assaad S, Costanian C, Haddad C, Tannous F. Sleep patterns and disorders among university students in Lebanon. J Res Health Sci 2014;14(3):198-204.

15. Lemma S, Gelaye B, Berhane Y, Worku A, Williams MA. Sleep quality and its psychological correlates among university students in Ethiopia: a cross-sectional study. BMC Psychiatry. 2012;12(237):1-7. doi: 10.1186/1471244X-12-237

16. Kang JH, Chen SC. Effects of an irregular bedtime schedule on sleep quality, daytime sleepiness, and fatigue among university students in Taiwan. BMC Public Health 2009;9(248):1-6. doi: 10.1186/1471-2458-9-248
17. Cates ME, Clark A, Woolley TW. Saunders A. Sleep quality among pharmacy students. Am J Pharm Educ 2015;79(1):1-6. doi: 10.5688/ajpe79109

18. Rique GLN, Fernandes Filho GMC, Ferreira ADC, de Sousa-Munoz RL. Relationship between chronotype and quality of sleep in medical students at the Federal University of Paraiba, Brazil. Sleep Sci. 2014;7(2):96-102. doi: 10.1016/j.slsci.2014.09.004

19. Felden EPG, Leite CR, Rebelatto CF, Andrade RD, Beltrame TS. Sleep in adolescents of different socioeconomic status: a systematic review. Rev Paul Pediatr. 2015;33(4):467-73. doi: 10.1016/j.rpped.2015.01.011

20. Vuori I, Urponen H, Hasan J, Partinen M. Epidemiology of exercise effects on sleep. Acta Physiol Scand Suppl. 1988;574:3-7.

21. Singh NA, Clements KM, Fiatarone MA. A randomized controlled trial of the effect of exercise on sleep. Sleep 1997;20(2):95-101. doi: 10.1093/sleep/20.2.95

22. Higuchi S, Motohashi Y, Liu Y, Maeda A. Effects of playing a computer game using a bright display on presleep physiological variables, sleep latency, slow wave sleep and REM sleep. J Sleep Res. 2005;14(3):267273. doi: $10.1111 /$ j.1365-2869.2005.00463.x

\section{Author Contribution:}

BO: Did data collection, statistical analysis and manuscript writing.

BO: Is Responsible for the accuracy and integrity of the research.

NMA: Conceived, designed and editing of manuscript. 